\title{
Grazing patterns and habitat selection of the Scottish Blackface compared with a crossbred, using GPS Satellite telemetry collars
}

\author{
E McCloskey ${ }^{1}$, J H McAdam ${ }^{1,2}$
}

${ }^{1}$ Queens University, Belfast, United Kingdom, ${ }^{2}$ Agri-Food and Biosciences Institute (AFBI), Belfast, United Kingdom

Email: e_mccloskey21@hotmail.com

Introduction Environmentally sustainable grazing regimes are an important aspect of domestic livestock farming in upland hill areas. In order to achieve such grazing regimes an understanding of the relationship between plants and animals must be established. This requires knowledge of the foraging behaviour of the animal, such as diet selection spatial distribution, foraging patterns. The collection of such can be the most difficult aspect of the study however; global positioning system (GPS) technology can provide a suitable solution (Turner et al., 2000). The aim of this study was to investigate grazing patterns, habitat selection and spatial distribution of the Scottish Blackface, a traditional hill sheep breed, compared with a crossbred, Texel X Scottish Blackface in a natural free ranging environment with the use of GPS telemetry collars.

Materials and methods The study was carried out at Glenwherry hill farm, animals involved in this study were two year old females, pure Scottish Blackface and Texel X Scottish Blackface (Texel XBF) reared on the hill farm. The flock was a combination of both breeds and contained up to 120 females, grazing an area of the hill (163 hectares) during MayOctober. Randomly selected ewes were fitted with GPS collars, two ewes from each breed and returned to flock and grazed as normal. The collars were programmed to record GPS locations at 30 minutes intervals between 06:00am-22:00pm (day) and 60 minutes intervals between 22:00pm-06:00am (night). Monitoring took place during May to October 2008. Four GPS collars were available, collars were changed on to different ewes approximately every 4 weeks. Results were obtained from 24 ewes, from which the results from eighteen ewes, nine per breed were suitable for analysis. Habitat mapping was carried out, aerial photos were used as a base, followed by ground mapping. Information was entered into ArcView GIS 3.2. habitat maps were created. Collar data was also entered into ArcView GIS 3.2. and combine with habitat data. Occurrence and frequency of habitats visited by ewes was identified. Results were recorded for, percentage occurrence on habitats, altitude, area covered and distance moved. Data were analysed by Analysis of Variance using Genstat. Analysing occurrence on habitats present over 24 hour periods. Area covered and distance travelled were analysed by two sided t test using Genstat.

Table 1 Percentage occurrence on habitats, altitude, area covered and distance travelled by Scottish blackface and Texel XBF ewes, monitored by GPS Collars

\begin{tabular}{|c|c|c|c|c|c|c|c|c|}
\hline & \multicolumn{2}{|l|}{ Ewe genotype } & \multirow[b]{2}{*}{ SEM } & \multirow[b]{2}{*}{ P-value } & \multirow[b]{2}{*}{ Sig } & \multirow{2}{*}{\multicolumn{3}{|c|}{$\begin{array}{l}\text { habitats ranked in order of preference } \\
\text { of habitat by grazing ewes }\end{array}$}} \\
\hline & Scottish Blackface & Texel XBF & & & & & & \\
\hline Blanket bog & 12.58 & 9.60 & 1.37 & 0.005 & ** & Habitat & Area \% & Rank \\
\hline Degraded blanket bog & 20.67 & 18.78 & 1.96 & 0.499 & NS & Blanket bog & 49 & 4 \\
\hline Marshy Grassland & 40.02 & 52.47 & 3.57 & 0.025 & * & Degraded blanket bog & 27 & 3 \\
\hline Unimproved & 26.73 & 19.15 & 3.79 & 0.175 & NS & Marshy Grassland & 22 & 1 \\
\hline Altitude (m) & 306.81 & 299.49 & 1.42 & 0.006 & $* *$ & Unimproved & 2 & 2 \\
\hline Area covered (ha) & 5.99 & 4.62 & 0.59 & 0.035 & * & & & \\
\hline Distance Travelled (m) & 1.89 & 1.20 & 0.21 & 0.005 & $* *$ & & & \\
\hline
\end{tabular}

Results Scottish Blackface occurred more often in blanket bog habitats than the Texel XBF, (P>0.005). Texel XBF occurred more often in Marshy Grassland habitats $(\mathrm{P}>0.025)$ than the Scottish blackface. No significant differences were found between breeds on degraded blanket bog or unimproved habitats. Both Scottish Blackface and Texel XBF occurred most often in Marshy habitats $40.02 \%$ and $52.47 \%$ respectively and occurred least often in Blanket bog habitats $12.58 \%$ and $9.60 \%$ respectively. Scottish Blackface were found to grazed at higher altitudes, on average $7 \mathrm{~m}$ higher than Texel $\mathrm{XBF}(\mathrm{P}>0.006)$. Significant differences were found between breeds for both area covered and distance travelled per day, $(\mathrm{P}>0.035)$ and $(\mathrm{P}>0.005)$ respectively.

Conclusion Both breeds show higher preferences for grass based habitats, with Scottish blackface ewes showing higher preferences for upland habitats such as blanket bog than Texel XBF, this supports previous work (McCloskey et al., 2009). Scottish Blackface ewes display better characteristics for grazing and managing vegetation on hill environments as they graze over a larger area and move higher up the hill, they also spend more time grazing on the various habitats present such as blanket bog, this is a consideration for upland management. The use of GPS collars has enabled the collection of a range of spatio-temporal information over an extensive area. This shows the potential for developing a more detailed analysis of animals grazing in extensive environments through the use of GPS equipment.

Acknowledgements Scholarship funding from DARD is gratefully acknowledged

\section{References}

McCloskey, E., McAdam, J.H. and Carson A.F. 2009. Habitat selection of crossbred ewes on hill farms in

Northern Ireland. Proceedings of the Agricultural Research Forum, 137

Turner, L.W., Udal, M.C., Larson, B.T. and Shearer, S.A. 2000. Monitoring cattle behaviour and pasture use with GPS and GIS. Canadian Journal of Animal Science 80, 405-413 